\title{
Focus on Early COPD: Definition and Early Lung Development
}

\author{
Weichang Yang \\ Fengyuan Li \\ Can Li \\ Jiaqi Meng \\ Ying Wang
}

Department of Respiratory and Critical Care Medicine, Nanchang First Hospital, Nanchang University, Nanchang, 330000, jiangxi, People's Republic of China
Correspondence: Fengyuan Li Nanchang First Hospital, Nanchang, 330000, Jiangxi, People's Republic of China

Tel +86-15770737599

Email yangweichang1996@163.com

\begin{abstract}
Chronic obstructive pulmonary disease (COPD) is a disease with high incidence rate and mortality rates worldwide. It is the third leading cause of death in the world. Nevertheless, little progress has been made in treating and preventing the disease. Under these circumstances, the concept of "early COPD" was proposed. Although this concept is not new, most health-care workers do not fully understand early COPD and tend to confuse it with mild COPD. In this review, we mainly discuss the definition of early COPD and the developmental trajectory of lung function. Although patients with early COPD have no symptoms, their lung function is already lower than that of normal people. A relatively complete definition is needed to identify this group of people. Reduced lung function is the diagnostic criterion for COPD, but lung development is a long-term dynamic process. In addition to smoking and air pollution, we should pay more attention to prenatal and childhood risk factors, for example, parents smoking, birth weight, preterm birth, mode of delivery, childhood respiratory infections and childhood asthma. Health-care workers need to be fully aware of early COPD, to reduce the morbidity of COPD and take effective measures to prevent these risk factors.
\end{abstract}

Keywords: early COPD, definition, early lung development

\section{Introduction}

Chronic obstructive pulmonary disease (COPD) is a disease with high incidence and mortality rates worldwide that is caused by airway and alveolar abnormalities, and is characterized by irreversible airflow limitation. ${ }^{1}$ Furthermore, COPD is expected to be a leading cause of death worldwide by $2030 .^{2}$ With the increase in air pollution and the speed of aging worldwide, COPD is expected to become the main economic burden of human chronic diseases in the future. ${ }^{3}$ Worryingly, COPD is more common in younger populations. Previous studies have identified that tobacco and fine particulate matter are the major risk factors for COPD, ${ }^{4}$ which mainly affects adults. However, such is not the case. Early life events are getting more attention, also affecting those under the age of 18 .

Lung development is a complicated process, that is influenced by many factors. ${ }^{5}$ Exposure to risk factors often occurs decades before abnormal lung function, respiratory symptoms and forced expiratory volume in 1 second $\left(\mathrm{FEV}_{1}\right)$ decline. ${ }^{6}$ COPD usually presents with small airway obstruction in the early stage, and it takes decades to develop slowly from small airway obstruction to the stage of $\mathrm{FEV}_{1}$ decline. ${ }^{7}$ These pathological changes may begin in the fetus and manifest in adulthood. First, this review discusses some of the controversies surrounding the 
definition of early COPD. Second, but importantly, we focus on the risk factors associated with an early natural history of COPD.

\section{Search Strategy and Selection Criteria}

We searched "early COPD", "COPD”, "genetics", "maternal smoking", "low birth weight /very low birth weight", "preterm birth", "maternal nutrition", "mode of delivery", "vitamin D deficiency", "childhood smoking", "air Pollution", "childhood respiratory infections", "childhood asthma", "manual working class and overcrowding", "risk factors", "definition", "lung development" and the different combinations of them on PubMed and Web of science before August 30, 2021. All articles were published in English and related to COPD or early COPD. We excluded some articles whose resources were not available. We reviewed the reviews and original researches in this area, then cited relevant articles.

\section{The Definition of Early COPD}

The definition of early COPD has been around for a long time, and a major controversy has been the unclear distinction between "mild COPD" and "early COPD". "Early" means the time of disease progression is early, while "mild" refers to the degree of disease, and there is no complete overlap between "mild COPD" and "early COPD". The definition of early COPD is similar to that of "early diabetes", "early Parkinson's", "early cardiovascular disease" and other early diseases. "Early" represents the pathophysiological changes occurring in the early stage of the natural history of disease, aiming to provide effective prevention strategies for the further development of the disease and reduce the fatality rate of the disease.

There is still no consensus on the definition at home and abroad. COPD is complex and heterogeneous, which means that each individual has an independent natural history, ${ }^{8,9}$ Genetics, environment, smoking, air pollution and early life events. These risk factors complicate the description of disease definition.

Prior to 2006, the guidelines of GOLD included a "GOLD 0" category, which mainly included people with high risk factors such as long-term smoking and air pollution. ${ }^{10}$ A large proportion of smoking patients did not progress from "GOLD 0" to "GOLD 1"; however, the classification was removed in 2007. Even to date, most studies confuse the concept of "mild" and "early". Early
COPD is usually considered GOLD1-2, which could lead to biased results. For "mild COPD", the GOLD was clearly defined as follows: ${ }^{11} 1$ ) $\mathrm{FEV}_{1} / \mathrm{FVC}<70 \%$ (inhalation of bronchodilator); and 2) $\mathrm{FEV}_{1} \geq 80 \%$ of the predicted values. At present, "FEV $1 / \mathrm{FVC}<70 \%$ " is used as the GOLD standard in the international guidelines for the diagnosis of COPD. ${ }^{5} \mathrm{FEV}_{1}$ and forced vital capacity (FVC) decline with age, and $\mathrm{FEV}_{1}$ declines faster than FVC. ${ }^{12}$ Since the international guidelines failed to correct for age, the elderly are over-diagnosed and the younger population is underdiagnosed. ${ }^{13}$ Nonetheless, there are no clear diagnostic criteria for early COPD. In 2017, Martinez proposed that diagnosis of early COPD should include (Table 1) 1) age $<50$ years and smoking quantity $>10$ packs/year; and 2) meeting any of the following criteria:1) $\mathrm{FEV}_{1} / \mathrm{FVC}<\mathrm{LLN}$ (post-bronchodilators); 2) chest computer tomography (CT) scan showed small airway obstruction or thickened airway walls; and 3) lung function decreased rapidly, with decline in $\mathrm{FEV}_{1}>60 \mathrm{~mL} /$ year. ${ }^{14}$ The definition excluded other chronic lung diseases except asthma. In 2020, Yunus Colak conducted a study based on Martinez's definition showing that less than $24 \%$ of young adults in the general population with early COPD develop clinical COPD 10 years later, depending on the amount of smoking exposure, suggesting that smoking exposure should be redefined because there is less tobacco exposure in the young population. ${ }^{15}$

Martinez et al proposed the definition of "early COPD", which focused on smokers but ignored the group of non-smokers and effects of early life events. They have noted the effects of early life events in his article, while failed to add them in definition. The followings point out the shortcomings of Martinez's definition and provide directions for future definition (Table 2). 1)

Table I Definition of Mild COPD and Early COPD

\begin{tabular}{|c|c|}
\hline Mild COPD & Early COPD \\
\hline $\begin{array}{l}\text { I) } \mathrm{FEV} / \mathrm{FVC}<70 \% \\
\text { (post-bronchodilators) }\end{array}$ & $\begin{array}{l}\text { I) }>50 \text { year of age and smoking }>10 \text { packs } / \\
\text { year }\end{array}$ \\
\hline $\begin{array}{l}\text { 2) } \mathrm{FEV}_{1}>80 \% \text { predicted } \\
\text { value }\end{array}$ & $\begin{array}{l}\text { 2) Meet any of the following: } \\
\text { FEV,/FVC<LLN (post-bronchodilators); } \\
\text { Chest CT showed small airway } \\
\text { obstruction or thickened airway walls; } \\
\text { Lung function reduced rapidly; with the } \\
\text { decline in } F E V_{1}>60 \mathrm{~mL} / \text { year }\end{array}$ \\
\hline
\end{tabular}

Note: Other known chronic lung diseases were excluded except for asthma. Abbreviations: $\mathrm{FEV}_{1}$, forced expiratory volume in I second; FVC, forced vital capacity; LLN, lower limit of normal; COPD, chronic obstructive pulmonary disease; $\mathrm{CT}$, computer tomography. 
Table 2 Disadvantages and Future Directions for Early COPD

\begin{tabular}{|c|c|c|}
\hline Early COPD & Disadvantages & Future \\
\hline $\begin{array}{l}\text { I) }<50 \text { year of age and smoking }>10 \\
\text { packs/year }\end{array}$ & $\begin{array}{l}\text { - Age }<50 \text { years should be adjusted earlier. } \\
\text { - Smoking exposure should be redefined. } \\
\text { - } 25-45 \% \text { with COPD are non-smokers, resulting in } \\
\text { missed diagnosis in some patients. }\end{array}$ & $\begin{array}{l}\text { - Adjust the range of age and number of } \\
\text { cigarettes smoked. } \\
\text { - Antenatal and childhood risk factors } \\
\text { should be added in early COPD. }\end{array}$ \\
\hline \multicolumn{3}{|l|}{ 2) Meet any of the following: } \\
\hline $\mathrm{FEV}_{\mathrm{I}} / \mathrm{FVC}<\mathrm{LLN}$ (post-bronchodilators); & $\begin{array}{l}\text { - LLN is the value before the inhalation of } \\
\text { bronchodilators. }\end{array}$ & $\begin{array}{l}\text { - Change post-bronchodilators to } \\
\text { prebronchodilators. }\end{array}$ \\
\hline $\begin{array}{l}\text { Chest CT showed small airway } \\
\text { obstruction or thickened airway walls; }\end{array}$ & $\begin{array}{l}\text { - The threshold for CT scan abnormalities are not } \\
\text { clear. }\end{array}$ & $\begin{array}{l}\text { - More studies are needed to clarify } \\
\text { thresholds. }\end{array}$ \\
\hline $\begin{array}{l}\text { Lung function reduced rapidly; with the } \\
\text { decline in } \mathrm{FEVI}>60 \mathrm{~mL} / \text { year; }\end{array}$ & $\begin{array}{l}\text { - FEV , can also decrease with acute pulmonary } \\
\text { inflammation, but it can later return to normal. } \\
\text { - The majority of adult COPD patients progress } \\
\text { without accelerated decline in lung function. } \\
\text { - Symptomatology is an important basis of COPD. }\end{array}$ & $\begin{array}{l}\text { - The duration of } F E V_{\text {, decrease by } 60 \mathrm{~mL} /} \\
\text { year should be specifically defined. } \\
\text { - The symptoms (cough or sputum } \\
\text { production) should be considered. }\end{array}$ \\
\hline
\end{tabular}

Abbreviations: FEV , forced expiratory volume in I s; FVC, forced vital capacity; LLN, lower limit of normal; COPD, chronic obstructive pulmonary disease; CT, computer tomography.

Age $<50$ years should be adjusted earlier, a study indicates that $4 \%$ to $13 \%$ of early adults show lung function decline. ${ }^{16}$ 2) $25-45 \%$ with COPD are non-smokers, resulting in missed diagnosis in some patients. 3) lower limit of normal (LLN) is the value before the inhalation of bronchodilators, but the definition just the opposite. 4) The duration of $\mathrm{FEV}_{1}$ decrease by $60 \mathrm{~mL} /$ year should be specifically defined. For example, $\mathrm{FEV}_{1}$ can also decrease with acute pulmonary inflammation, but it can later return to normal. ${ }^{17}$ 5) The majority of adult COPD patients progress without accelerated decline in lung function. ${ }^{18,19}$ Therefore, the use of reduced lung function as a diagnostic criterion also misses some patients. 6) COPD is a clinical diagnosis. Martinez's definition relies on lung function and CT but ignores symptomatology, which is an important basis for diagnosing COPD,${ }^{20}$ therefore, symptomatology should be added in the definition of early COPD. Even with its many shortcomings, the definition is still valuable, as screening people with early COPD in large cohort studies regardless of their lung function status and excluding individuals unlikely to develop clinical COPD later in life is effective. ${ }^{21}$

\section{The Early Development of Lung Function}

Lung development is a continuous process throughout life. The development of the bronchial tree begins with the formation of lung buds at 21-28 days of gestation, followed by the formation of a complete bronchial tree at 317 weeks. $^{22}$ Lung function peaks at approximately 20 years of age. ${ }^{23}$ The plateau (lung function remains roughly constant) is a special stage of lung development that occurs at approximately 20-25 years of age, and then lung function slowly declines with age. ${ }^{24,25}$ Smoking is considered to be a major factor in the decline of lung function during this period. ${ }^{26}$ Of course, individuals with different risk factors experience different changes in lung function, such as reduced lung growth, reduced maximum lung function, episodic accelerated loss of lung function and late accelerated loss of lung function. ${ }^{23}$

Lung development is usually determined by genetic and environmental factors, such as asthma, childhood respiratory tract infection, nutrition and maternal smoking. ${ }^{27}$ Complete lung function is largely dependent on early life. ${ }^{28}$ Smoking, genetics and air pollution were suggested as the main risk factors for COPD in a previous study, ${ }^{4}$ apparently, early events of life were neglected. In 1991, Barker pointed out that low birth weight affects lung development, intrauterine growth irreversibly affects airway development and childhood respiratory disease further reduces lung function. ${ }^{29}$ Afterward, several studies have suggested that early events of life (maternal smoking, ${ }^{30,31}$ low birth weight, ${ }^{32}$ preterm birth $^{33,34}$ ) are also risk factors in the process of COPD, which may explain why more than $50 \%$ of COPD patients 
are nonsmokers. In summary, lung development is a dynamic and multifactorial process. The following sections describe in detail the various stages of lung development and their risk factors (Figure 1). This section aims to explain the early risk factors for lung function and the importance of understanding early COPD.

\section{Genetics}

Genetic factors play an important role in the development of COPD and determine the beginning of lung development. In the 20th century, researchers realized the connection between $\alpha 1$-antitrypsin Deficiency (AATD) and COPD. The mechanisms including antiproteinase theory, Chemotactic mediators and A1AT polymerization. Studies have shown that AATD deficiency increases the incidence of COPD and exacerbates airway obstruction in smokers. ${ }^{35}$ At present, AATD is the only confirmed genetic risk factor for COPD and asthma, ${ }^{36}$ while there is a lack of research on whether AATD enters COPD earlier than those without
AATD. Costa believes screening for AATD is necessary to facilitate early diagnosis and treatment. ${ }^{37}$ Intravenous augmentation appears to be a therapy to delay AATD, but corresponding evidence-based information is scarce. ${ }^{38}$ Gene and Stem cell therapies are the direction of future research.

Other related genes include ADAM33, SOX540 and TNS1. ${ }^{39}$ These genetics ultimately lead to reduced lung function in adulthood by airway hyperactivity, lung growth and repair damage and airway remodeling. ${ }^{40}$ These genes are considered to be high-risk genes for COPD. Prevention and treatment of "genetic COPD" is the focus of future research.

\section{Antenatal Risk Factors}

Lung development begins when the fetus is in the womb. From week 4 to week 7 (embryonic), the main bronchus is formed. From week 7 to week 16 (pseudoglandular stage), the bronchus continues to subdivide into terminal bronchioles. From the week 16 to the week 27 (tubule stage), the

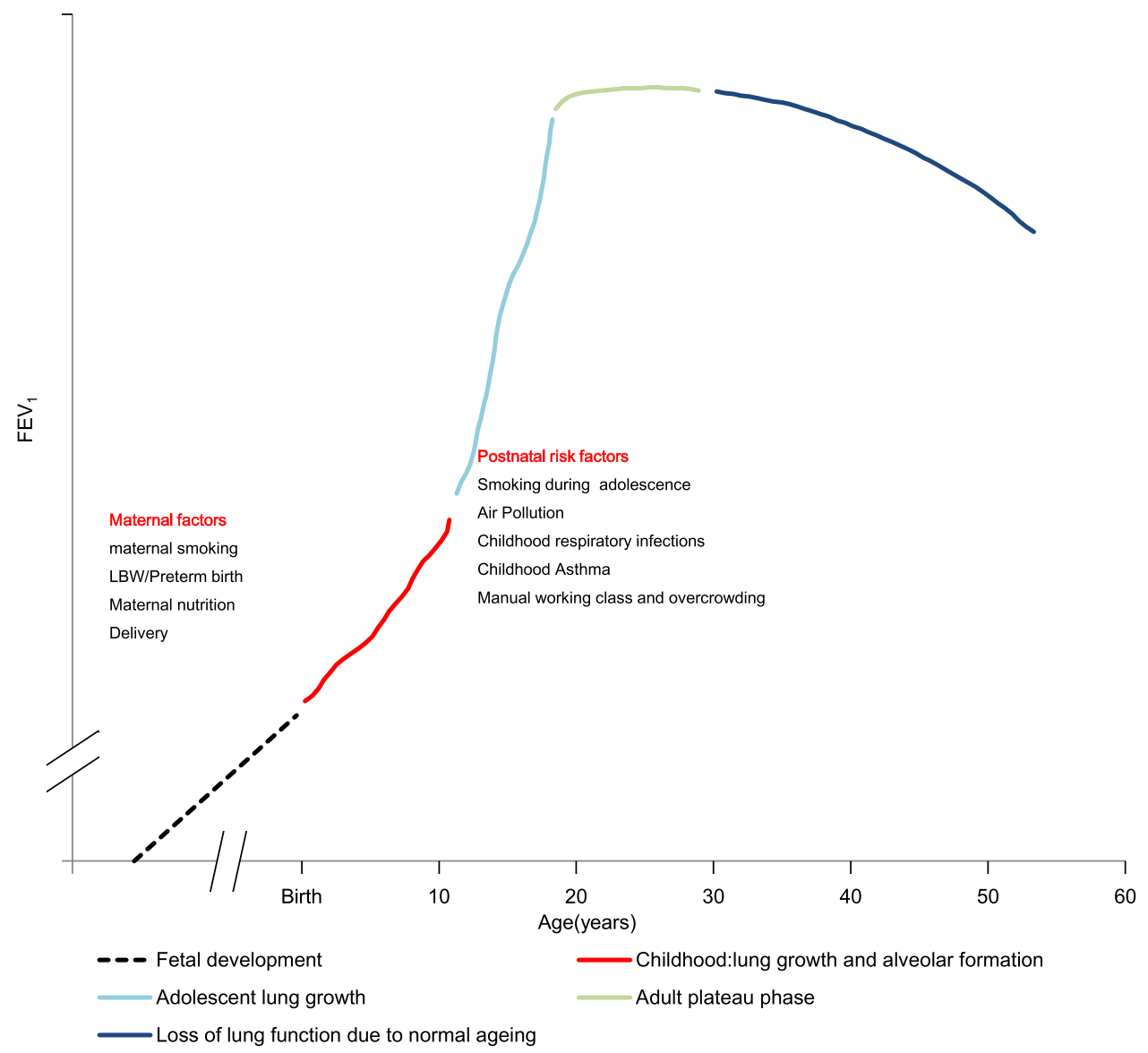

Figure I Natural history of lung function and risk factors at different stages. This figure shows the developmental trajectory of lung function, which is influenced by prenatal and postnatal factors. Reprinted with permission from Rennard SI, Drummond MB. Early chronic obstructive pulmonary disease: definition, assessment, and prevention. Lancet. 2015;385(9979): 1778-1788. Copyright 2015 Elsevier Ltd. All rights reserved. ${ }^{23}$

Abbreviations: FEVI, forced expiratory volume in I second; LBW, low birth weight. 
airway branch is completed, and the primitive balloon is formed. At this stage, with the increase in interstitial peripheral vasculature, the cuboid epithelial cells in the sac differentiate into Type I and Type II pulmonary cells. From week 27 (cystic phase), preacinar airway growth, additional respiratory bronchiole development and acinar formation are observed. ${ }^{27}$ Then, the alveoli begin to develop; at 29 weeks of gestation, 30 million alveoli gradually develop to 150 million at term. ${ }^{41,42}$ In this stage, lung development can be affected by maternal smoking, low birth weight, maternal nutrition, preterm birth and other factors, ${ }^{27}$ which seriously impair lung function, promoting the progression of COPD.

\section{Maternal Smoking}

Maternal smoking is considered to be the primary risk factor in early events of life affecting lung function and is strongly associated with low birth weight. ${ }^{43}$ In 2006 , Sam Pattenden reviewed the health and parental tobacco exposure of 53,897 children at 12 centers and found that maternal smoking was independently associated with wheezing, asthma and allergic rhinitis in children and that asthma was the most closely associated with maternal smoking. ${ }^{44}$ Beyer et al recruited 288 patients diagnosed with COPD from 2003 to 2004 and collected information on parental smoking status and occupational exposure. They suggested that maternal smoking was a risk factor for reduced $\mathrm{FEV}_{1}$ in COPD. Maternal smoking may increase the risk of asthma and reduce lung function and lung development in teenagers. The effect was more pronounced among girls than boys. ${ }^{45} \mathrm{Li}$ et al conducted a case-control study on 338 children diagnosed with asthma in the first 5 years of life in southern California and 570 healthy children, suggesting that grandmaternal smoking may increase the risk of childhood asthma. ${ }^{46}$ This result suggested that maternal smoking could damage lung development in grandchildren, but the specific mechanism remains unclear.

Intrauterine hypoxia, reduced utero-placental blood flow due to nicotine, placental toxicity, or toxic growth limits of multiple toxins in tobacco smoke are considered the main pathological mechanisms of maternal smoking. ${ }^{47}$ The harmful substances in cigarettes (nicotine and carbon monoxide) are released into blood circulation, which leads to the above changes. Furthermore, nicotine can easily pass through the placental barrier, affecting fetal lung development continuously. $^{48}$ In a study of 19 infants who were diagnosed with sudden infant death syndrome (SIDS), prenatal smoking was found to be a risk factor for airway change in infants, and the change was mainly airway stenosis, which contributed to reduced lung function in neonates. ${ }^{49}$ Maternal smoking was also associated with airway hyperresponsiveness (AHR), ${ }^{50}$ and AHR is a major mechanism of asthma. The detailed mechanism needs further study.

\section{Low Birth Weight, Preterm Birth}

Low birth weight (LBW) is defined as a birth weight of the baby $<2500 \mathrm{~g}$, which can be caused by maternal malnutrition or other diseases. In a retrospective study of 164 pairs of observers conducted by J W Matthes in 1995, there was no correlation between LBW and reduced lung function in adolescents. ${ }^{51}$ Subsequently, S O Shaheen came to the same conclusion. ${ }^{52}$ However, D A Lawlor conducted in a meta-analysis and found that after adjusting for age, height and smoking, birth weight was moderately positively correlated with lung function. ${ }^{53}$ Thereafter, many studies have identified LBW and preterm birth as risk factors for COPD. ${ }^{54-56}$ A retrospective cohort study from China indicated that LBW may increase the risk of adult reduced lung function in China, and there was a positive correlation between LBW and $\mathrm{FEV}_{1}, \mathrm{FVC}$ and peak expiratory flow (PEF) ${ }^{57}$ Maternal smoking is also a risk factor for LBW and preterm birth. ${ }^{58}$ The effects of maternal smoking should be considered when studying the effects of LBW and preterm birth.

A birth weight $<1500 \mathrm{~g}$ is considered as very low birth weight (VLBW). Many studies have shown that VLBW is related to an increased risk of COPD. ${ }^{59-61}$ Since VLBW usually leads to bronchopulmonary dysplasia (BPD), the major pathological changes of BPD are reduced pulmonary alveolar septation, reduced microvascular crosssectional area and airway injury. ${ }^{62}$ These changes result in potential airflow limitation and abnormal lung volume. ${ }^{63}$ VLBW, preterm birth and smoking during pregnancy are risk factors for BPD. ${ }^{64}$

Preterm birth refers to infants whose gestational age is less than 37 weeks. Eva Berggren Brostrom followed preterm babies and compared them with normal fetuses. The risk ratios of obstructive respiratory disease and asthma for babies born before 32 weeks gestation were 2.77 and 5.67 respectively, suggesting that preterm birth is a hazardous factor for obstructive pulmonary disease. ${ }^{56}$ In 2011, a cohort study in Sweden suggested 
that the gestational age of infants born between 23 and 27 weeks was related to an increased incidence of asthma in adulthood, while there was not effect for infants born between 28 and 32 weeks or 33 and 36 weeks. $^{65}$ Reduced lung volume is usually caused by preterm birth, which affects lung function in adolescents.

\section{Other Maternal Factors}

Similarly, other prenatal factors such as maternal nutrition, ${ }^{66}$ mode of delivery, ${ }^{67}$ and vitamin $\mathrm{D}$ deficiency ${ }^{68}$ were also identified as high-risk factors of lung development. A study from the Dutch Famine collected lung function and $\operatorname{IgE}$ from 726 subjects at that time, suggesting that poor maternal nutrition is connected with the high incidence of asthma in adults, especially in early pregnancy. ${ }^{69}$ The association of cesarean section with lung development requires further research.

\section{Childhood Risk Factors}

As mentioned above, lung development after growth can be divided into three stages: lung development before the age of 20 (rising stage), roughly unchanged lung function between the ages of 20 and 25 (plateau stage), and slow decline after that (declining stage). Childhood smoking, fine particulate matter, childhood respiratory infections,

Table 3 Risk Factors for Lung Development at Different Life Stages

\begin{tabular}{|c|c|}
\hline $\begin{array}{l}\text { The Stage of } \\
\text { Life }\end{array}$ & The Risk Factors for Lung Function \\
\hline \multirow[t]{2}{*}{ Genetics } & $\alpha I$-antitrypsin deficiency \\
\hline & ADAM33, SOX5, TNSI \\
\hline \multirow{4}{*}{$\begin{array}{l}\text { Antenatal } \\
\text { period }\end{array}$} & Maternal smoking \\
\hline & LBW/VLBW, Preterm birth \\
\hline & Maternal nutrition \\
\hline & Mode of delivery Vitamin D deficiency \\
\hline \multirow[t]{4}{*}{ Childhood } & Childhood smoking \\
\hline & Air Pollution \\
\hline & Childhood respiratory infections \\
\hline & $\begin{array}{c}\text { Childhood asthma Manual working class and } \\
\text { overcrowding }\end{array}$ \\
\hline
\end{tabular}

Abbreviations: LBW, low birth weight; VLBW, very low birth weight. asthma and manual working class and overcrowding are major hazardous factors at these stages (Table 3). ${ }^{28,70-72}$

\section{Childhood Smoking}

Tobaccos is a recognized hazardous factor for COPD and other lung diseases. Tobacco exposure shortens the plateau stage duration of $\mathrm{FEV}_{1} \cdot{ }^{25}$ Lung function damage usually occurs in adolescents, because it is not fully developed at that time. $\mathrm{FEV}_{1} / \mathrm{FVC}$ ratios were significantly reduced in adolescent smokers and were associated with increased peripheral airway resistance. ${ }^{73}$ A recent cohort study from Europe showed that smoking-related lung function damage occurs in early life and is completely unreactive to bronchodilators, suggesting that lung function damage is long-term and irreversible. $^{74}$ In 2007, a study was performed in Spain, on the influence of smoking on lung function in adolescents aged $16-20$ years. FVC, $\mathrm{FEV}_{1}, \mathrm{FEV}_{1} / \mathrm{FVC}$ and $\mathrm{PEF} \mathrm{Y}_{\mathrm{Y}} \mathrm{MEF}_{25-75 \%}$ were lower in the passive and active smoking groups than in the nonsmoking group, and women were worse than men. ${ }^{75}$ Concerningly, while the percentage of adolescents who smoke has declined in recent years, a large percentage of the teen population still uses e-cigarettes, and they are used at an earlier age. ${ }^{76}$ E-cigarettes have many advantages over cigarettes, but they still contain nicotine, which can cause lung and cardiovascular diseases. ${ }^{77}$ The use of e-cigarettes is more likely to induce the incidence of smoking. ${ }^{78,79}$ Therefore, the prevention of smoking among adolescents, especially among women, should be considered.

\section{Air Pollution}

Air pollution exposure is a risk factor of COPD and decreased lung function. ${ }^{80-82}$ These pollution particles, mainly including in $\mathrm{PM}_{2.5}, \mathrm{NO}_{\mathrm{x}}, \mathrm{O}_{3}$ and others, are considered to have diameters $<2.5 \mu \mathrm{m}$. Saeha Shin conducted a 15-year cohort study collecting the incidence of COPD and asthma among subjects who were exposed to air pollution. Air pollution is a risk factor of COPD, not asthma. ${ }^{83}$ Long-term exposure to these polluted particles induces airway inflammation and oxidative stress in bronchial epithelial cells, which may contribute to the development of COPD. Anais Havet et al believed that the decreased lung function caused by air pollution was related to small airway obstruction. ${ }^{84}$ Unfortunately, air pollution is more likely to threaten children and increase the risk of respiratory infections. ${ }^{85}$ Furthermore, childhood exposure to pollution 
particles is associated with poor lung function in adolescents. Similarly, exposure to air pollution during pregnancy can adversely affect fetal lung function. ${ }^{86}$ It has also been suggested that maternal exposure to air pollution may alter the trajectory of lung development, making children more susceptible to respiratory disease later in life. ${ }^{87}$ The mechanism may be due to the transmission of pollution particles through the placental barrier, causing a series of pathological changes. ${ }^{88}$

A cohort study of 7071 adults 45 to 84 years of age was conducted between 2000 and 2018 in six large cities of the US It focused on the association of lung development in people chronically exposed to air pollution. The results showed that $\mathrm{PM}_{2.5}, \mathrm{O}_{3}, \mathrm{NOx}$ and black carbon in the environment were obviously related to the increase in the percentage of emphysema every 10 years, and $\mathrm{O}_{3}$ was correlated with the decline in FVC. ${ }^{89}$ The risk of COPD caused by indoor pollution particles is higher than that caused by outdoor particles. This may be due to spending much more time indoors than outdoors each day. Indoor environment optimization is easier to carry out, reducing indoor pollution particles should be considered, and it is more urgent in children and pregnant women.

\section{Childhood Respiratory Infections}

Respiratory infections are common diseases in childhood, and affect the most critical stage of lung development and immunity. The pathogenesis are mainly respiratory syncytial virus (RSV), adenovirus and coronavirus, among which the most common is $\mathrm{RSV}^{90}$ At present, there are different opinions on the impact of childhood respiratory infections on lung development. The mainstream view is that childhood respiratory infections are related to adult lung function. However, some studies suggest that the evidence is insufficient. $^{91,92}$

In the 1990s, S O Shaheen considered the association between childhood respiratory infections and COPD to be difficult to test. However, in Hertfordshire and Derbyshire, England, pneumonia before 2 years of age was associated with a reduced mean $\mathrm{FEV}_{1}$ after adjustment for age and height. ${ }^{93}$ In a multicenter study from Europe, childhood respiratory infection or lung disease was associated with asthma in adulthood, with lower $\mathrm{FEV}_{1}, \mathrm{FVC}$, and $\mathrm{FEV}_{1} / \mathrm{FVC}$ than in adults without a history of respiratory infection. ${ }^{94}$

In a study from 10,192 adult smokers in the US, an early history of respiratory infections by questionnaire, and lung function scans and chest CT scan were measured. Childhood pneumonia was found to be related to COPD, reduced $\mathrm{FEV}_{1}$ and $\mathrm{FVC}$ in adult smokers, and increased airway wall thickness in these populations on CT scans. ${ }^{95}$ However, the study failed to explain the correlation between childhood pneumonia and nonsmokers with COPD. Peter suggested that severe respiratory illness in childhood is associated with reduced $\mathrm{FEV}_{1}$ in middle age, based on changes in lung function at age 14 and 49 to 51 years. $^{96}$ Childhood pneumonia may reduce maximum $\mathrm{FEV}_{1}$ rather than decreased the rate of declined $\mathrm{FEV}_{1}{ }^{97}$

In contrast, Agnes E Marossy conducted a large cohort study of 1158 adults born in the United Kingdom in 1958. Spirometry measurements were collected at 35 and 45 years of age. Subjects were divided into asthmatic, asthmatic bronchitis, and normal categories. The mean reduction in $\mathrm{FEV}_{1}$ was $35 \mathrm{~mL} /$ year, but the rate of decline was not associated with early respiratory disease. It was clear that a history of whooping cough was not related to $\mathrm{FEV}_{1}$ and FVC in adulthood. $^{92}$ Subsequently, a birth cohort study by Geir Haland showed that respiratory infections before age 2 did not affect lung function before age $10,{ }^{91}$ while it failed to track lung function until adulthood. The main goal of subsequent research should be to determine whether respiratory infections cause reduced lung function and the stage of reduction.

We believe that the differences between the two viewpoints are mainly related to the following aspects: 1) it is difficult to exclude the influence of intrauterine development factors and the postnatal environmental when studying the association with respiratory infections and lung development; 2) most studies collect information based on parental recall, with large bias and unreliable data and conclusions;3) many studied subjects came from families with low socioeconomic status, and most of the studies did not exclude the effect of the low socioeconomic status from lung function. 4) it is possible that only some pathogens impair lung function, but most studies have not examined respiratory tract etiology.

\section{Childhood Asthma}

The definition of early COPD does not exclude asthma because asthma is a risk factor for irreversible airway obstruction. A number of long-term cohort studies now suggest that childhood asthma increases the risk of COPD in adulthood, and independent of smoking, childhood asthma could be considered an independent risk factor for COPD. ${ }^{98-100}$ Airway remodeling is the main mechanism, and histological features include in inflammatory cell infiltration (macrophages and lymphocytes), proliferation of fibroblasts and myofibroblasts, angiogenesis, connective tissue fibrosis, and tissue destruction. ${ }^{101}$ Interestingly, 
many adults with a history of childhood allergic asthma or aspirin exacerbated respiratory disease show irreversible airway obstruction. ${ }^{102,103}$

\section{Manual Working Class and Overcrowding}

Manual working class and overcrowding may also be called socioeconomic status, reflecting the unequal distribution of socioeconomic resources, which is common in the groups of middle and low income countries. It usually represents low income levels, low education and poor nutrition. Manual social class and home overcrowding accelerate $\mathrm{FEV}_{1}$ reduction after adulthood, suggested in a prospective study by Allinson. ${ }^{72}$ Kanervisto concluded that poor socioeconomic status not only reflected the low income, education and malnutrition, but also increased the risk of asthma and COPD. ${ }^{104}$ Although people are aware of the detriment of socioeconomic status, little preventive measures are taken.

\section{Conclusion}

Early COPD is not a novel concept, but many health-care workers fail to realize its importance, confusing its definition with mild COPD. Lung function in early life is most vulnerable to risk factors. A study from Mexican shows that $13.7 \%$ of COPD patients are asymptomatic, ${ }^{105}$ while this group reaches $35.3 \%$ in China. ${ }^{106}$ Therefore, we think asymptomatic early COPD should also be paid to receive increased attention. It is easier to understand asymptomatic early COPD in terms of lung function development, people with reduced lung function (do not reach $\mathrm{FEV}_{1} / \mathrm{FVC}<0.7$ ) but no respiratory symptoms, the future definitions of early COPD should focus on this group.

A large proportion of people with COPD are nonsmokers. Martinez failed to identify this group, and antenatal and childhood risk factors should be added in early COPD, at the same time, while adjusting the range of age and number of cigarettes smoked. Early life events and genetics are risk factors of COPD. We suggest that making rating scale to describe early life events, the duration of air pollution exposure and times of childhood respiratory infections should be considered in rating scale, while there is a lack of relevant studies, further study should aim to quantify early life events. Early life events contribute to the identification of COPD in nonsmokers, while individual differences in early life experiences add to the difficulty of defining this group.

COPD continues to have increasing morbidity and mortality globally, yet we still lack effective means to prevent and reduce it. We need to understand that the development of COPD is a long-term cumulative process, and lung function development begins in the embryonic stage. Lung development is affected by many risk factors, and these factors could result in decreased lung function, while further cohort studies should focus on the occurrence of early COPD rather than lung function injury. Therefore, it is necessary to recognize the dynamic process of lung development to diagnose early COPD, and monitoring lung function changes regularly in people with early risk factors could help with early prevention and reduce the incidence of COPD.

\section{Author Contributions}

All authors made a significant contribution to the work reported, whether that is in the conception, study design, execution, acquisition of data, analysis and interpretation, or in all these areas; took part in drafting, revising or critically reviewing the article; gave final approval of the version to be published; have agreed on the journal to which the article has been submitted; and agree to be accountable for all aspects of the work.

\section{Disclosure}

The authors report no conflicts of interest in this work.

\section{References}

1. Halpin DMG, Criner GJ, Papi A, et al. Global initiative for the diagnosis, management, and prevention of chronic obstructive lung disease. the 2020 GOLD science committee report on COVID-19 and chronic obstructive pulmonary disease. Am J Respir Crit Care Med. 2021;203(1):24-36. doi:10.1164/rccm.202009-3533SO

2. Mathers CD, Loncar D, Lu M, Yao W-Z, Zhong N-S. Projections of global mortality and burden of disease from 2002 to 2030. PLoS Med. 2006;3(11):e442. doi:10.1371/journal.pmed.0030442

3. Lozano R, Naghavi M, Foreman K, et al. Global and regional mortality from 235 causes of death for 20 age groups in 1990 and 2010: a systematic analysis for the Global Burden of Disease Study 2010. Lancet. 2012;380 (9859):2095-2128. doi:10.1016/S0140-6736(12)61728-0

4. Hattab Y, Alhassan S, Balaan M, Lega M, Singh AC. Chronic obstructive pulmonary disease. Crit Care Nurs Q. 2016;39(2):124-130. doi:10.1097/CNQ.0000000000000105

5. Vestbo J, Hurd SS, Agustí AG, et al. Global strategy for the diagnosis, management, and prevention of chronic obstructive pulmonary disease: GOLD executive summary. Am J Respir Crit Care Med. 2013;187(4):347-365. doi:10.1164/rccm.201204-0596PP

6. Petty TL. The history of COPD. Int J Chron Obstruct Pulmon Dis. 2006;1(1):3-14. doi:10.2147/copd.2006.1.1.3

7. Hogg JC, Chu F, Utokaparch S, et al. The nature of small-airway obstruction in chronic obstructive pulmonary disease. $N$ Engl $J$ Med. 2004;350(26):2645-2653. doi:10.1056/NEJMoa032158

8. Sapey E, Bafadhel M, Bolton CE, Wilkinson T, Hurst JR, Quint JK. Building toolkits for COPD exacerbations: lessons from the past and present. Thorax. 2019;74(9):898-905. doi:10.1136/thoraxjnl-2018213035 
9. Williams NP, Coombs NA, Johnson MJ, et al. Seasonality, risk factors and burden of community-acquired pneumonia in COPD patients: a population database study using linked health care records. Int J Chron Obstruct Pulmon Dis. 2017;12:313-322. doi:10.2147/COPD.S121389

10. Pauwels RA, Buist AS, Calverley PM, Jenkins CR, Hurd SS Global strategy for the diagnosis, management, and prevention of chronic obstructive pulmonary disease. NHLBI/WHO Global Initiative for Chronic Obstructive Lung Disease (GOLD) workshop summary. Am J Respir Crit Care Med. 2001;163 (5):1256-1276. doi:10.1164/ajrccm.163.5.2101039

11. Singh D, Agusti A, Anzueto A, et al. Global strategy for the diagnosis, management, and prevention of chronic obstructive lung disease: the GOLD science committee report 2019. Eur Respir J. 2019;53(5):1900164. doi:10.1183/13993003.001642019

12. Lu HH, Zeng HH, Chen Y. Early chronic obstructive pulmonary disease: a new perspective. Chronic Dis Transl Med. 2021;7 (2):79-87. doi:10.1016/j.cdtm.2021.02.003

13. Swanney MP, Ruppel G, Enright PL, et al. Using the lower limit of normal for the FEV1/FVC ratio reduces the misclassification of airway obstruction. Thorax. 2008;63(12):1046-1051. doi:10.1136/thx.2008.098483

14. Martinez FJ, Han MK, Allinson JP, et al. At the root: defining and halting progression of early chronic obstructive pulmonary disease. Am J Respir Crit Care Med. 2018;197(12):1540-1551. doi:10.1164/rccm.201710-2028PP

15. Çolak Y, Afzal S, Nordestgaard BG, Lange P, Vestbo J. Importance of early COPD in young adults for development of clinical copd: findings from the Copenhagen general population study. Am J Respir Crit Care Med. 2021;203(10):1245-1256. doi:10.1164/rccm.202003-0532OC

16. Agustí A, Noell G, Brugada J, Faner R. Lung function in early adulthood and health in later life: a transgenerational cohort analysis. Lancet Respir Med. 2017;5(12):935-945. doi:10.1016/ S2213-2600(17)30434-4

17. Bhatt SP. Early chronic obstructive pulmonary disease or early detection of mild disease? Am J Respir Crit Care Med. 2018;198 (3):411-412. doi:10.1164/rccm.201802-0257LE

18. Bui DS, Lodge CJ, Burgess JA, et al. Childhood predictors of lung function trajectories and future COPD risk: a prospective cohort study from the first to the sixth decade of life. Lancet Respir Med. 2018;6(7):535-544. doi:10.1016/S2213-2600(18) 30100-0

19. Lange P, Celli B, Agustí A, et al. Lung-function trajectories leading to chronic obstructive pulmonary disease. $N$ Engl $J$ Med. 2015;373(2):111-122. doi:10.1056/NEJMoa1411532

20. Viviers PJ, van Zyl-smit RN. Chronic obstructive pulmonary disease-diagnosis and classification of severity. South Afr Med j. 2015;105(9):786-788. doi:10.7196/samjnew.8421

21. Ritchie AI, Martinez FJ. The challenges of defining early chronic obstructive pulmonary disease in the general population. Am J Respir Crit Care Med. 2021;203(10):1209-1210. doi:10.1164/ rccm.202011-4176ED

22. Smith LJ, McKay KO, van Asperen PP, Selvadurai H, Fitzgerald DA. Normal development of the lung and premature birth. Paediatr Respir Rev. 2010;11(3):135-142. doi:10.1016/j. prrv.2009.12.006

23. Rennard SI, Drummond MB. Early chronic obstructive pulmonary disease: definition, assessment, and prevention. Lancet. 2015;385(9979):1778-1788. doi:10.1016/S01406736(15)60647-X

24. Sherrill DL, Lebowitz MD, Knudson RJ, Burrows B. Continuous longitudinal regression equations for pulmonary function measures. Eur Respir J. 1992;5(4):452-462.
25. Tager IB, Segal MR, Speizer FE, Weiss ST. The natural history of forced expiratory volumes. Effect of cigarette smoking and respiratory symptoms. Am Rev Respir Dis. 1988;138 (4):837-849. doi:10.1164/ajrccm/138.4.837

26. Fletcher C, Peto R. The natural history of chronic airflow obstruction. $B r$ Med J. 1977;1(6077):1645-1648. doi:10.1136/ bmj.1.6077.1645

27. Narang I, Bush A. Early origins of chronic obstructive pulmonary disease. Semin Fetal Neonatal Med. 2012;17(2):112-118. doi:10.1016/j.siny.2012.01.002

28. Martinez FD, Drazen JM. Early-life origins of chronic obstructive pulmonary disease. $N$ Engl J Med. 2016;375(9):871-878. doi:10.1056/NEJMra1603287

29. Barker DJ, Godfrey KM, Fall C, Osmond C, Winter PD, Shaheen SO. Relation of birth weight and childhood respiratory infection to adult lung function and death from chronic obstructive airways disease. BMJ. 1991;303(6804):671-675. doi:10.1136/bmj.303.6804.671

30. McEvoy CT, Spindel ER. Pulmonary effects of maternal smoking on the fetus and child: effects on lung development, respiratory morbidities, and life long lung health. Paediatr Respir Rev. 2017;21:27-33. doi:10.1016/j.prrv.2016.08.005

31. Beyer D, Mitfessel H, Gillissen A. Maternal smoking promotes chronic obstructive lung disease in the offspring as adults. Eur $J$ Med Res. 2009;14 Suppl 4(Suppl4):27-31. doi:10.1186/2047783X-14-S4-27

32. Balte P, Karmaus W, Roberts G, Kurukulaaratchy R, Mitchell F, Arshad H. Relationship between birth weight, maternal smoking during pregnancy and childhood and adolescent lung function: a path analysis. Respir Med. 2016;121:13-20. doi:10.1016/j. rmed.2016.10.010

33. Simpson SJ, Turkovic L, Wilson AC, et al. Lung function trajectories throughout childhood in survivors of very preterm birth: a longitudinal cohort study. Lancet Child Adolesc Health. 2018;2 (5):350-359. doi:10.1016/S2352-4642(18)30064-6

34. Kwinta P, Pietrzyk JJ. Preterm birth and respiratory disease in later life. Expert Rev Respir Med. 2010;4(5):593-604. doi:10.1586/ ers. 10.59

35. Mayer AS, Stoller JK, Vedal S, et al. Risk factors for symptom onset in PI*Z alpha-1 antitrypsin deficiency. Int J Chron Obstruct Pulmon Dis. 2006;1(4):485-492. doi:10.2147/copd.2006.1.4.485

36. Janssen R, Piscaer I, Franssen FME, Wouters EFM. Emphysema: looking beyond alpha-1 antitrypsin deficiency. Expert Rev Respir Med. 2019;13(4):381-397. doi:10.1080/17476348.2019.1580575

37. da Costa $\mathrm{CH}$, Noronha Filho AJ, Marques ESRMF, et al. Alpha 1 -antitrypsin deficiency in patients with chronic obstructive pulmonary disease patients: is systematic screening necessary? BMC Res Notes. 2019;12(1):10. doi:10.1186/ s13104-018-4043-9

38. Edgar RG, Patel M, Bayliss S, Crossley D, Sapey E, Turner AM. Treatment of lung disease in alpha-1 antitrypsin deficiency: a systematic review. Int $J$ Chron Obstruct Pulmon Dis. 2017;12:1295-1308. doi:10.2147/COPD.S130440

39. Huang X, Mu X, Deng L, et al. The etiologic origins for chronic obstructive pulmonary disease. Int J Chron Obstruct Pulmon Dis. 2019;14:1139-1158. doi:10.2147/COPD.S203215

40. Yuan C, Chang D, Lu G, Deng X. Genetic polymorphism and chronic obstructive pulmonary disease. Int J Chron Obstruct Pulmon Dis. 2017;12:1385-1393. doi:10.2147/COPD.S134161

41. Hislop AA, Wigglesworth JS, Desai R. Alveolar development in the human fetus and infant. Early Hum Dev. 1986;13(1):1-11. doi:10.1016/0378-3782(86)90092-7

42. Langston C, Kida K, Reed M, Thurlbeck WM. Human lung growth in late gestation and in the neonate. Am Rev Respir Dis. 1984;129(4):607-613. 
43. Wang X, Zuckerman B, Pearson C, et al. Maternal cigarette smoking, metabolic gene polymorphism, and infant birth weight. JAMA. 2002;287(2):195-202. doi:10.1001/jama.28 7.2.195

44. Pattenden S, Antova T, Neuberger M, et al. Parental smoking and children's respiratory health: independent effects of prenatal and postnatal exposure. Tob Control. 2006;15(4):294-301. doi:10.1136/tc.2005.015065

45. Dai X, Dharmage SC, Lowe AJ, et al. Early smoke exposure is associated with asthma and lung function deficits in adolescents. J Asthma. 2017;54(6):662-669. doi:10.1080/02770903.2016.12 53730

46. Li YF, Langholz B, Salam MT, Gilliland FD. Maternal and grandmaternal smoking patterns are associated with early childhood asthma. Chest. 2005;127(4):1232-1241. doi:10.1378/ chest.127.4.1232

47. Rogers JM. Smoking and pregnancy: epigenetics and developmental origins of the metabolic syndrome. Birth Defects Res. 2019;111(17):1259-1269. doi:10.1002/bdr2.1550

48. Dempsey DA, Benowitz NL. Risks and benefits of nicotine to aid smoking cessation in pregnancy. Drug Safety. 2001;24 (4):277-322. doi:10.2165/00002018-200124040-00005

49. Elliot J, Vullermin P, Robinson P. Maternal cigarette smoking is associated with increased inner airway wall thickness in children who die from sudden infant death syndrome. Am J Respir Crit Care Med. 1998;158(3):802-806. doi:10.1164/ajrccm.158.3.9709 055

50. Young S, Le Souëf PN, Geelhoed GC, Stick SM, Turner KJ, Landau LI. The influence of a family history of asthma and parental smoking on airway responsiveness in early infancy. $N$ Engl J Med. 1991;324(17):1168-1173. doi:10.1056/NEJM1 99104253241704

51. Matthes JW, Lewis PA, Davies DP, Bethel JA. Birth weight at term and lung function in adolescence: no evidence for a programmed effect. Arch Dis Child. 1995;73(3):231-234. doi:10.1136/adc.73.3.231

52. Shaheen SO, Sterne JA, Tucker JS, Florey CD. Birth weight, childhood lower respiratory tract infection, and adult lung function. Thorax. 1998;53(7):549-553. doi:10.1136/thx.53.7.549

53. Lawlor DA, Ebrahim S, Davey Smith G. Association of birth weight with adult lung function: findings from the British Women's Heart and Health Study and a meta-analysis. Thorax. 2005;60(10):851-858. doi:10.1136/thx.2005.042408

54. Savran O, Ulrik CS. Early life insults as determinants of chronic obstructive pulmonary disease in adult life. Int J Chron Obstruct Pulmon Dis. 2018;13:683-693. doi:10.2147/COPD.S153555

55. $\mathrm{Mu} \mathrm{M,} \mathrm{Ye} \mathrm{S,} \mathrm{Bai} \mathrm{MJ,} \mathrm{et} \mathrm{al.} \mathrm{Birth} \mathrm{weight} \mathrm{and} \mathrm{subsequent} \mathrm{risk} \mathrm{of}$ asthma: a systematic review and meta-analysis. Heart Lung Circ. 2014;23(6):511-519. doi:10.1016/j.hlc.2013.11.018

56. Broström EB, Akre O, Katz-Salamon M, Jaraj D, Kaijser M. Obstructive pulmonary disease in old age among individuals born preterm. Eur J Epidemiol. 2013;28(1):79-85. doi:10.1007/ s10654-013-9761-7

57. Pei L, Chen G, Mi J, et al. Low birth weight and lung function in adulthood: retrospective cohort study in China, 1948-1996. Pediatrics. 2010;125(4):e899-905. doi:10.1542/peds.2008-3086

58. Cox B, Martens E, Nemery B, Vangronsveld J, Nawrot TS. Impact of a stepwise introduction of smoke-free legislation on the rate of preterm births: analysis of routinely collected birth data. BMJ. 2013;346:f441. doi:10.1136/bmj.f441

59. Yang J, Kingsford RA, Horwood J, et al. Lung function of adults born at very low birth weight. Pediatrics. 2020;145(2): e20192359. doi:10.1542/peds.2019-2359

60. Saarenpää HK, Tikanmäki M, Sipola-Leppänen M, et al. Lung function in very low birth weight adults. Pediatrics. 2015;136 (4):642-650. doi:10.1542/peds.2014-2651
61. Schmalisch G, Wilitzki S, Roehr CC, Proquitté H, Bührer C. Development of lung function in very low birth weight infants with or without bronchopulmonary dysplasia: longitudinal assessment during the first 15 months of corrected age. BMC Pediatr. 2012;12:37. doi:10.1186/1471-2431-12-37

62. Jobe AH. Mechanisms of lung injury and bronchopulmonary dysplasia. Am J Perinatol. 2016;33(11):1076-1078. doi:10.1055/ s-0036-1586107

63. Simpson SJ, Hall GL, Wilson AC. Lung function following very preterm birth in the era of "new" bronchopulmonary dysplasia. Respirology. 2015;20(4):535-540. doi:10.1111/resp.12503

64. Kalikkot Thekkeveedu R, Guaman MC, Shivanna B. Bronchopulmonary dysplasia: a review of pathogenesis and pathophysiology. Respir Med. 2017;132:170-177. doi:10.1016/j. rmed.2017.10.014

65. Crump C, Winkleby MA, Sundquist J, Sundquist K. Risk of asthma in young adults who were born preterm: a Swedish national cohort study. Pediatrics. 2011;127(4):e913-920. doi:10.1542/peds.2010-2603

66. Faridy EE. Effect of maternal malnutrition on surface activity of fetal lungs in rats. $J$ Appl Physiol. 1975;39(4):535-540. doi:10.1152/jappl.1975.39.4.535

67. Thavagnanam S, Fleming J, Bromley A, Shields MD, Cardwell CR. A meta-analysis of the association between Caesarean section and childhood asthma. Clin Exp Allergy. 2008;38(4):629-633. doi:10.1111/j.1365-2222.2007.02780.x

68. Zosky GR, Berry LJ, Elliot JG, James AL, Gorman S, Hart PH. Vitamin D deficiency causes deficits in lung function and alters lung structure. Am J Respir Crit Care Med. 2011;183 (10):1336-1343. doi:10.1164/rccm.201010-1596OC

69. Lopuhaä CE, Roseboom TJ, Osmond C, et al. Atopy, lung function, and obstructive airways disease after prenatal exposure to famine. Thorax. 2000;55(7):555-561. doi:10.1136/thorax.55.7.555

70. Bush A. Lung development and aging. Ann Am Thorac Soc. 2016;13(Suppl 5):S438-s446. doi:10.1513/AnnalsATS.201602112AW

71. Postma DS, Bush A, van den Berge M. Risk factors and early origins of chronic obstructive pulmonary disease. Lancet. 2015;385(9971):899-909. doi:10.1016/S0140-6736(14)60446-3

72. Allinson JP, Hardy R, Donaldson GC, Shaheen SO, Kuh D, Wedzicha JA. Combined impact of smoking and early-life exposures on adult lung function trajectories. Am J Respir Crit Care Med. 2017;196(8):1021-1030. doi:10.1164/rccm.201703-0506OC

73. Thacher JD, Schultz ES, Hallberg J, et al. Tobacco smoke exposure in early life and adolescence in relation to lung function. Eur Respir J. 2018;51(6):1702111. doi:10.1183/13993003.02111-2017

74. Arshad SH, Hodgekiss C, Holloway JW, et al. Association of asthma and smoking with lung function impairment in adolescence and early adulthood: the Isle of Wight Birth Cohort Study. Eur Respir J. 2020;55(3):1900477. doi:10.1183/13993003.00477-2019

75. Suárez López de Vergara RG, Galván Fernández C, Oliva Hernández C, Doménech Martínez E, Dorta JM, Dorta Suárez M. Función pulmonar y exposición al humodel tabaco en adolescentes. Anales de Pediatria. 2007;67(6):559-566. doi:10.1016/S1695-4033(07)70804-4

76. Evans-Polce R, Veliz P, Boyd CJ, McCabe VV, McCabe SE. Trends in E-cigarette, cigarette, cigar, and smokeless tobacco use among US adolescent cohorts, 2014-2018. Am J Public Health. 2020;110(2):163-165. doi:10.2105/AJPH.2019.305421

77. Balakumar P, Kaur J. Is nicotine a key player or spectator in the induction and progression of cardiovascular disorders? Pharmacol Res. 2009;60(5):361-368. doi:10.1016/j.phrs.2009.0 6.005

78. Peterson LA, Hecht SS. Tobacco, e-cigarettes, and child health. Curr Opin Pediatr. 2017;29(2):225-230. doi:10.1097/MOP.0000 000000000456 
79. Chatterjee K, Alzghoul B, Innabi A, Meena N. Is vaping a gateway to smoking: a review of the longitudinal studies. Int J Adolesc Med Health. 2016;30(3). doi:10.1515/ijamh-20160033

80. Doiron D, de Hoogh K, Probst-Hensch N, et al. Air pollution, lung function and COPD: results from the population-based UK Biobank study. Eur Respir J. 2019;54(1):1802140. doi:10.1183/ 13993003.02140-2018

81. Wang C, Xu J, Yang L, et al. Prevalence and risk factors of chronic obstructive pulmonary disease in China (the China Pulmonary Health $[\mathrm{CPH}]$ study): a national cross-sectional study. Lancet. 2018;391(10131):1706-1717. doi:10.1016/S01406736(18)30841-9

82. Mehta AJ, Miedinger D, Keidel D, et al. Occupational exposure to dusts, gases, and fumes and incidence of chronic obstructive pulmonary disease in the Swiss Cohort Study on air pollution and lung and heart diseases in adults. Am J Respir Crit Care Med. 2012;185(12):1292-1300. doi:10.1164/rccm.201110-1917OC

83. Shin S, Bai L, Burnett RT, et al. Air pollution as a risk factor for incident chronic obstructive pulmonary disease and asthma. A 15-year population-based Cohort Study. Am J Respir Crit Care Med. 2021;203(9):1138-1148. doi:10.1164/rccm.201909-1744OC

84. van Donkelaar A, Martin RV, Brauer M, Boys BL. Use of satellite observations for long-term exposure assessment of global concentrations of fine particulate matter. Environ Health Perspect. 2015;123(2):135-143. doi:10.1289/ehp.1408646

85. Li S, Williams G, Jalaludin B, Baker P. Panel studies of air pollution on children's lung function and respiratory symptoms: a literature review. J Asthma. 2012;49(9):895-910. doi:10.3109/ 02770903.2012.724129

86. Korten I, Ramsey K, Latzin P. Air pollution during pregnancy and lung development in the child. Paediatr Respir Rev. 2017;21:38-46. doi:10.1016/j.prrv.2016.08.008

87. Veras MM, de Oliveira Alves N, Fajersztajn L, Saldiva P. Before the first breath: prenatal exposures to air pollution and lung development. Cell Tissue Res. 2017;367(3):445-455. doi:10.10 07/s00441-016-2509-4

88. Saenen ND, Martens DS, Neven KY, et al. Air pollution-induced placental alterations: an interplay of oxidative stress, epigenetics, and the aging phenotype? Clin Epigenetics. 2019;11(1):124. doi:10.1186/s13148-019-0688-z

89. Wang M, Aaron CP, Madrigano J, et al. Association between long-term exposure to ambient air pollution and change in quantitatively assessed emphysema and lung function. JAMA. 2019;322(6):546-556. doi:10.1001/jama.2019.10255

90. Zar HJ, Barnett W, Stadler A, Gardner-Lubbe S, Myer L, Nicol MP. Aetiology of childhood pneumonia in a well vaccinated South African birth cohort: a nested case-control study of the Drakenstein Child Health Study. Lancet Respir Med. 2016;4 (6):463-472. doi:10.1016/S2213-2600(16)00096-5

91. Håland $\mathrm{G}$, Lødrup Carlsen KC, Mowinckel P, et al. Lung function at $10 \mathrm{yr}$ is not impaired by early childhood lower respiratory tract infections. Pediatr Allergy Immunol. 2009;20(3):254-260. doi:10.1111/j.1399-3038.2008.00781.x

92. Marossy AE, Strachan DP, Rudnicka AR, Anderson HR. Childhood chest illness and the rate of decline of adult lung function between ages 35 and 45 years. Am J Respir Crit Care Med. 2007;175(4):355-359. doi:10.1164/rccm.200607-1023OC
93. Shaheen SO, Barker DJ, Holgate ST. Do lower respiratory tract infections in early childhood cause chronic obstructive pulmonary disease? Am J Respir Crit Care Med. 1995;151(5):1649-1651; discussion 1651-1642. doi:10.1164/ajrccm/151.5_Pt_1.1649

94. Dharmage SC, Erbas B, Jarvis D, et al. Do childhood respiratory infections continue to influence adult respiratory morbidity? Eur Respir J. 2009;33(2):237-244. doi:10.1183/09031936.00062907

95. Hayden LP, Hobbs BD, Cohen RT, et al. Childhood pneumonia increases risk for chronic obstructive pulmonary disease: the COPDGene study. Respir Res. 2015;16(1):115. doi:10.1186/ s12931-015-0273-8

96. Tennant PW, Gibson GJ, Parker L, Pearce MS. Childhood respiratory illness and lung function at ages 14 and 50 years: childhood respiratory illness and lung function. Chest. 2010;137 (1):146-155. doi:10.1378/chest.09-0352

97. Chan JY, Stern DA, Guerra S, Wright AL, Morgan WJ, Martinez FD. Pneumonia in childhood and impaired lung function in adults: a longitudinal study. Pediatrics. 2015;135(4):607-616. doi:10.1542/peds.2014-3060

98. Ali KM. Childhood asthma as a risk factor for adult chronic obstructive pulmonary disease: a systematic review and meta-analysis. Expert Rev Respir Med. 2020;1-7. doi:10.1080/ 17476348.2021.1864328

99. Tagiyeva N, Devereux G, Fielding S, Turner S, Douglas G. Outcomes of childhood asthma and wheezy bronchitis. A 50-Year Cohort Study. Am J Respir Crit Care Med. 2016;193 (1):23-30. doi:10.1164/rccm.201505-0870OC

100. Shirtcliffe P, Marsh S, Travers J, Weatherall M, Beasley R. Childhood asthma and GOLD-defined chronic obstructive pulmonary disease. Intern Med J. 2012;42(1):83-88. doi:10.1111/ j.1445-5994.2010.02238.x

101. Fehrenbach H, Wagner C, Wegmann M. Airway remodeling in asthma: what really matters. Cell Tissue Res. 2017;367 (3):551-569. doi:10.1007/s00441-016-2566-8

102. Mascia K, Haselkorn T, Deniz YM, Miller DP, Bleecker ER, Borish L. Aspirin sensitivity and severity of asthma: evidence for irreversible airway obstruction in patients with severe or difficult-to-treat asthma. $J$ Allergy Clin Immunol. 2005;116 (5):970-975. doi:10.1016/j.jaci.2005.08.035

103. Limb SL, Brown KC, Wood RA, et al. Irreversible lung function deficits in young adults with a history of childhood asthma. J Allergy Clin Immunol. 2005;116(6):1213-1219. doi:10.1016/j. jaci.2005.09.024

104. Kanervisto M, Vasankari T, Laitinen T, Heliövaara M, Jousilahti P, Saarelainen S. Low socioeconomic status is associated with chronic obstructive airway diseases. Respir Med. 2011;105(8):1140-1146. doi:10.1016/j.rmed.2011.03.008

105. Sansores RH, Velázquez-Uncal M, Pérez-Bautista O, VillalbaCaloca J, Falfán-Valencia R, Ramírez-Venegas A. Prevalence of chronic obstructive pulmonary disease in asymptomatic smokers. Int J Chron Obstruct Pulmon Dis. 2015;10:2357-2363. doi:10.2147/COPD.S91742

106. Lu M, Yao WZ, Zhong NS, et al. Asymptomatic patients of chronic obstructive pulmonary disease in China. Chin Med J. 2010;123(12):1494-1499. 


\section{Publish your work in this journal}

The International Journal of COPD is an international, peer-reviewed journal of therapeutics and pharmacology focusing on concise rapid reporting of clinical studies and reviews in COPD. Special focus is given to the pathophysiological processes underlying the disease, intervention programs, patient focused education, and self management protocols. This journal is indexed on PubMed Central, MedLine and CAS. The manuscript management system is completely online and includes a very quick and fair peer-review system, which is all easy to use. Visit http://www.dovepress.com/testimonials.php to read real quotes from published authors. 